\title{
OCULAR MANIFESTATION OF TUBERCULOUS MENINGITIS IN CHILDREN
}

Umesh Prasad Bhadani1 ${ }^{1}$ Ranjeet Kumar ${ }^{2}$

${ }_{1}^{1}$ Associate Professor, Department of Ophthalmology, Patna Medical College and Hospital, Patna, Bihar, India. 2Junior Resident, Department of Ophthalmology, Patna Medical College and Hospital, Patna, Bihar, India.

\section{BACKGROUND}

\section{ABSTRACT}

Tuberculous meningitis (TBM) is a prevalent disease in our country. Eyes are often involved in cases of tuberculous meningitis sooner or later in variable number of cases and permanent vision loss or nerve palsy may result.

\section{MATERIALS AND METHODS}

The present study was carried out in Patna Medical College and Hospital from Jan 2017 to Dec 2017 in children upto age 10 years. In total, 50 patients of Tuberculous meningitis were selected from cases of meningitis of varying aetiology. Pure cases of tuberculous meningitis were included for the present study and other causes of meningitis were excluded from the study.

\section{RESULTS}

Out of 50 cases of TBM in children, 10 cases of TBM had ocular complications.

\section{CONCLUSION}

Various ocular complications noted in the present study including conjugate deviations of eye and head, pupillary changes, vitreous haze, optic nerve changes, cranial nerve palsy and visual loss.

\section{KEY WORDS}

Tuberculous Meningitis (TBM), Pupillary Changes, Optic Nerve Involvement.

HOW TO CITE THIS ARTICLE: Bhadani UP, Kumar R. Ocular manifestation of tuberculous meningitis in children. J. Evolution Med. Dent. Sci. 2018;7(40):4397-4398, DOI: 10.14260/jemds/2018/980

\section{BACKGROUND}

The World Health Organization (WHO) had declared tuberculosis to be a global emergency, as it remains the most common single cause of morbidity and mortality (Centre for Disease Control and Prevention, 1994 and 2004; Duke Elder S and Perkin 2004). Classification of ophthalmic symptom was made according to the formula presented by Uhthoff as early as 1912 like myopathic paralysis, pupillary disturbance, stasis of optic nerve and choroidal tubercle (Uhthoff classification). ${ }^{1}$ The patient can present with fever, loss of appetite, disturbed sleep, photophobia, neurologic deficit, optic atrophy or may have an acute onset with convulsion and pyrexia. ${ }^{2}$ Due to lack of specific symptoms and signs in patients of tuberculous meningitis make it difficult for early diagnosis. Therefore, antitubercular therapy should be promptly initiated in any young infant with clinical presentation of meningitis in context of cerebrospinal fluid, white cell count less than 500 cells and lymphocyte predominance, hyponatraemia and hydrocephalus. ${ }^{3}$

\section{MATERIALS AND METHODS}

The hospital-based case study was carried out in all children of both sexes diagnosed with Tuberculous meningitis in upto age of 10 years of both sexes with ocular complication from Jan. 2017 to Dec. 2017 in Patna Medical College and Hospital.

'Financial or Other Competing Interest': None.

Submission 19-07-2018, Peer Review 18-09-2018,

Acceptance 24-09-2018, Published 01-10-2018.

Corresponding Author:

Ranjeet Kumar

$3^{\text {rd }}$ Year Junior Resident, Department of Ophthalmology,

Patna Medical College and Hospital,

Patna-800004, Bihar, India.

E-mail: dr.ranjeetpmch@gmail.com

DOI: $10.14260 /$ jemds $/ 2018 / 980$

\section{Inclusion and Exclusion Criteria}

Pure cases of Tuberculous meningitis were included for the present study, other causes of meningitis were excluded from the study.

\section{Materials Used}

1. Visual acuity.

2. Slit lamp examination.

3. Direct ophthalmoscopy.

4. Indirect ophthalmoscopy.

5. Fundus camera.

6. Chest x-ray.

7. Ultrasound A scan and B scan.

\section{RESULTS}

Out of 50 cases of TBM in children, 10 cases had ocular complication. Conjugate deviation of the eye and head had occurred in one case of TBM.

In pupillary changes dilated and fixed pupil noted in 2 cases of TBM, dilated and sluggish pupil noted in 2 cases of TBM and dilated and ill sustained in 2 cases of TBM. The prognosis in case of dilated and fixed pupil was gravest.

In posterior segment change 1 case of vitreous haze, 1 case of papillitis, 1 case of retrobulbar neuritis, 3 cases of papilloedema, 1 case of primary optic atrophy and 1 case of post neuritic optic atrophy was noticed in total 50 cases of TBM.

Visual loss of varying degree and nature was noted in 4 cases of TBM.

\begin{tabular}{|c|c|}
\hline Total Cases & Cases showing TBM \\
\hline 50 & $10(20 \%)$ \\
\hline \multicolumn{2}{|c|}{ Table 1. Showing Incidence of Ocular Complication } \\
\hline
\end{tabular}




\begin{tabular}{|c|c|}
\hline Total Cases & $\begin{array}{c}\text { Cases showing Conjugate Deviation } \\
\text { of the Eye and Head }\end{array}$ \\
\hline 50 & $1(2 \%)$ \\
\hline \multicolumn{2}{|c|}{ Table 2. Showing Incidence of Conjugate Deviation of the } \\
Eye and Head
\end{tabular}

\begin{tabular}{|c|c|c|}
\hline Total Cases & \multicolumn{2}{|c|}{ Cases showing Pupillary Changes } \\
\hline \multirow{3}{*}{50} & Dilated and fixed pupil & $2(4 \%)$ \\
\cline { 2 - 3 } & Dilated and sluggish pupil & $2(4 \%)$ \\
\cline { 2 - 3 } & Dilated with ill sustained & $2(4 \%)$ \\
\hline \multicolumn{2}{|c|}{ Table 3. Showing Incidence of Pupillary Changes } \\
\hline
\end{tabular}

Table 4. Posterior Segment Changes

\begin{tabular}{|c|c|}
\hline Total No. of Cases & Vitreous Haze \\
\hline 50 & $1(2 \%)$ \\
\hline \multicolumn{2}{|c|}{ Table 4A. Showing Incidence of Vitreous Haze of TBM Cases } \\
\hline
\end{tabular}

\begin{tabular}{|c|c|}
\hline Total No. of Cases & Papillitis \\
\hline 50 & $1(2 \%)$ \\
\hline \multicolumn{2}{|c|}{ Table 4B. Showing Incidence of Papillitis of TBM Cases } \\
\hline
\end{tabular}

\begin{tabular}{|c|c|}
\hline Total Number of Cases & Retrobulbar Neuritis \\
\hline 50 & $1(2 \%)$ \\
\hline Table 4C. Showing Incidence of Retrobulbar Neuritis of \\
TBM Cases \\
\hline
\end{tabular}

\begin{tabular}{|c|c|}
\hline Total No. of Cases & Papilloedema \\
\hline 50 & $3(6 \%)$ \\
\hline \multicolumn{2}{|c|}{ Table 4D. Showing Incidence of Papilloedema of TBM Cases } \\
\hline
\end{tabular}

\begin{tabular}{|c|c|}
\hline Total No. of Cases & Primary Optic Atrophy \\
\hline 50 & $1(2 \%)$ \\
\hline Table 4E. Showing Incidence of Primary Optic Atrophy of \\
TBM Cases \\
\hline
\end{tabular}

\begin{tabular}{|c|c|}
\hline Total No. of Cases & Post Neuritic Optic Atrophy \\
\hline 50 & $1(2 \%)$ \\
\hline $\begin{array}{c}\text { Table 4F. Showing Incidence of Post Neuritic Optic Atrophy } \\
\text { of TBM Cases }\end{array}$ \\
\hline
\end{tabular}

\begin{tabular}{|c|c|}
\hline Total No. of Cases & Total No. Cranial Nerve Palsy \\
\hline 50 & $4(8 \%)$ \\
\hline \multicolumn{2}{|c|}{ Table 5a. Showing Incidence of Nerve Palsy in TBM Cases } \\
\hline
\end{tabular}

\begin{tabular}{|c|l|l|}
\hline Total No. of Cases & \multicolumn{2}{|c|}{ Total no. Cranial Nerve Palsy } \\
\hline 50 & $\begin{array}{l}3^{\text {rd }} \text { Cranial Nerve } \\
\text { Palsy(unilateral) }\end{array}$ & $2(4 \%)$ \\
\cline { 2 - 3 } & $6^{\text {th }}$ cranial nerve palsy & $2(4 \%)$ \\
\hline \multicolumn{2}{|c|}{ Table 5b. Showing incidence of nerve palsy in TBM } \\
Cases
\end{tabular}

\begin{tabular}{|c|c|}
\hline $\begin{array}{c}\text { Total No. of } \\
\text { Cases }\end{array}$ & Visual Loss \\
\hline 50 & $4(8 \%)$ \\
\hline \multicolumn{2}{|c|}{ Table 6. Showing Incidence of Visual Loss in TBM Cases } \\
\hline
\end{tabular}

\section{DISCUSSION}

On comparing the present study with others, it can be concluded that incidence of ocular complication has shown an appreciable decline and permanent visual disability and nerve palsy also occur in less number of cases. But it should not be forgotten that permanent visual disability or nerve palsy still occur. So cases of TBM should be thoroughly managed and followed for long periods to tackle the problem efficiently in order to prevent or limit various ocular complication and sequelae.

\section{CONCLUSION}

It is observed that tubercular meningitis is more likely to produce ocular complication. ${ }^{4}$ Pupillary involvement may be due to the nerve involvement or due to pressure on the brain stem by dilation of third ventricle (Richman theory). ${ }^{5}$ There is often partial ocular paresis, usually of the $3^{\text {rd }}$ and $6^{\text {th }}$ cranial nerve. Bilateral third nerve paralysis is unknown. ${ }^{6}$ Because of close proximity of the meninges with the optic nerve, any inflammation of the meninges can lead to ocular manifestation like optic neuritis, optic atrophy, papilloedema, papillitis, cranial nerve involvement- mainly ( $3^{\text {rd }}$ and $6^{\text {th }}$ ) leading to lateral rectus palsy, ptosis and lagophthalmos.

\section{REFERENCES}

[1] Opthalmologic symptoms in patients with tuberculous meningitis, with or without miliary tuberculosis. Acta Opthalmologia 1960;38(61):18-46.

[2] Ghai OP, Paul VK, Bagga A. Ghai essential paediatrics. 7th edn. CBS Publisher 2009: p. 540.

[3] Tung YR, Lai MC, Lui CC, et al. Tuberculous meningitis in infancy. Pediatr Neurol 2002;27(4):262-6.

[4] Mishra RK. Ocular complication in meningitis. Proc AIOS 1970;31:115-9.

[5] Verma BM, Sriwastava SK, Srivastava JR. Ocular manifestation of tubercular meningitis and their prognostic value in children. Indian $\mathrm{J}$ Othalmol 1981;29(3):301-2.

[6] Ramanjit S, Radhika T. Parson's disease of eye. $20^{\text {th }}$ edn. Elsevier 2008: p. 490. 